\title{
Modernização à Brasileira
}

\section{Maria Elisa Cevasco ${ }^{1}$}

\begin{abstract}
Resumo
O artigo se propõe a descrever algumas das peculiaridades do funcionamento do capitalismo global na periferia, através do exame de ensaios do crítico cultural Roberto Schwarz, lidos como instrumentos de descoberta e de interpretação do projeto de modernização da sociedade brasileira.
\end{abstract}

Palavras-chave

Crítica cultural, modernização periférica, Roberto Schwarz.

Recebido em 12 de março de 2014

Aprovado em 9 de junho de 2014

CEVASCO, Maria Elisa. Modernização à brasileira. Revista do Instituto de Estudos Brasileiros, Brasil, n. 59, p. 191-212, dez. 2014. D0I: http://dx.doi.org/10.11606/issn.2316-901X.v0i59p191-212

I Universidade de São Paulo (USP, São Paulo, SP, Brasil). 


\title{
Modernization Brazilian Style
}

\author{
Maria Elisa Cevasco
}

\begin{abstract}
The article presents an examination of the peculiarities of global capitalism on the periphery. It does so through a reading of some of the essays written by the cultural critic Roberto Schwarz, which are considered as instruments for the discovery and interpretation of the project of modernization in Brazilian society.
\end{abstract}

Keywords

Cultural criticism, peripheral modernization, Roberto Schwarz. 


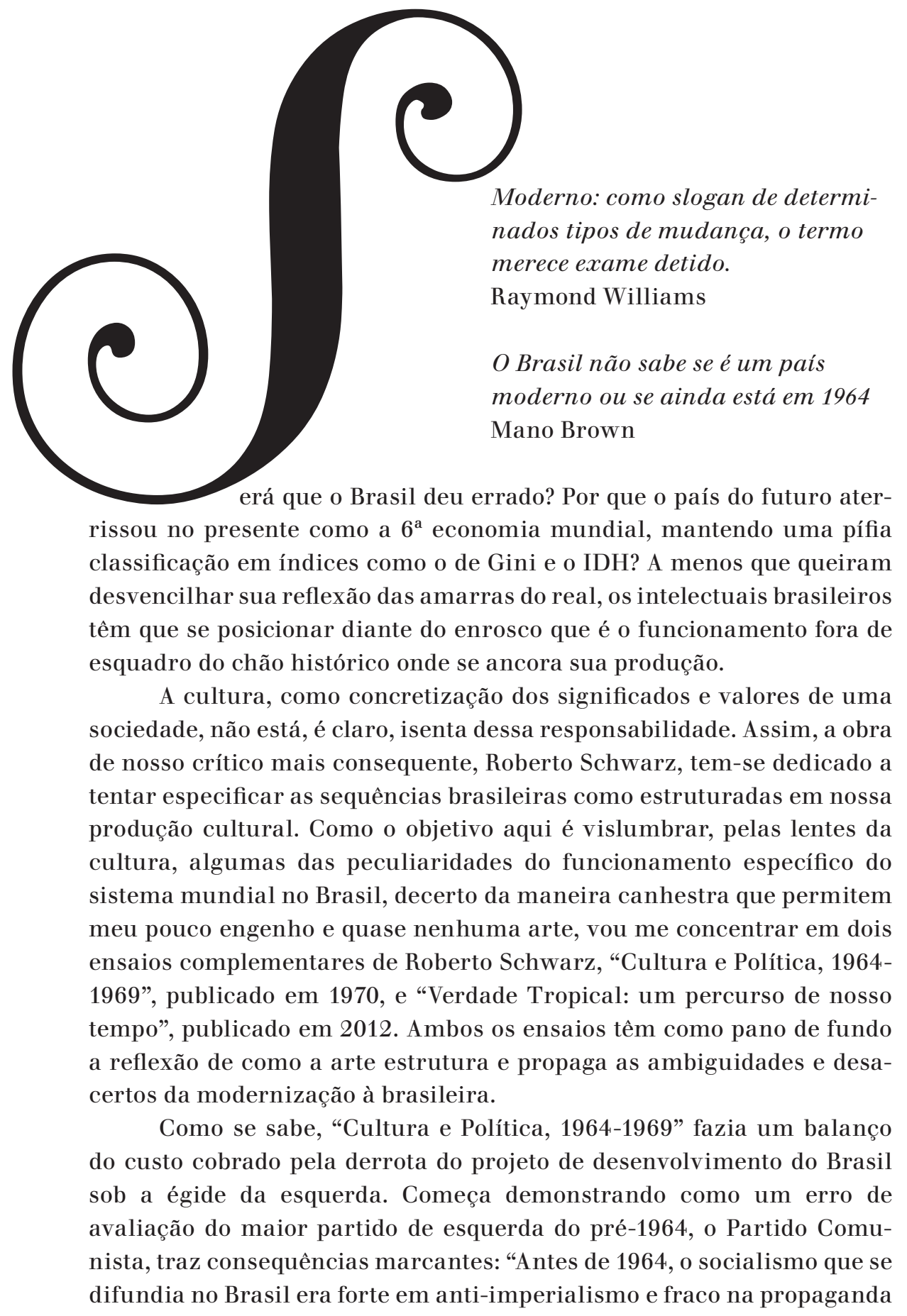


e na organização da luta de classes". ${ }^{2}$ Esta fraqueza se deve também à estratégia do Partido Comunista de unir-se à parte nacionalista e modernizante da burguesia nacional, vista como um aliado natural contra os aspectos arcaicos da sociedade brasileira.

Segundo Roberto Schwarz, a avaliação de que a dominação imperialista e o conservadorismo interno eram ligados e que não se podia mudar uma sem mudar a outra estava correta. Já a ideia de aliar-se com o inimigo de classe levou a uma visão "desdentada de marxismo", que abraçava a problemática burguesa de democratização e de modernização nacionalista. Um dos resultados foi um marxismo "especializado na inviabilidade do capitalismo, e não nos caminhos da revolução" (p. 78). Por esses rumos tortos, chegava-se à esquerda e à direita a uma visão sem contradições da modernização, desejo de todos e lastro de quase todas as avaliações do Brasil ${ }^{3}$. Sabemos as consequências políticas do equívoco do PC: no momento do golpe, as classes dominantes se uniram em torno do anticomunismo com os resultados que conhecemos para as esquerdas. Mas, aí um dos focos de interesse do ensaio, esse desastre político não impediu que o intenso fermento social desses tempos, em que o "país vibrava e as opções diante da história mundial” eram assunto do dia a dia, desembocasse em uma extraordinária floração cultural que logra figurar as linhas de força desse momento histórico ímpar e atinge ampla projeção internacional. No ensaio, ele destaca entre as grandes realizações culturais da época: o método revolucionário de alfabetização de Paulo Freire, a arquitetura baseada no sentido do coletivo e não de ornamentação burguesa, o teatro engajado, cada um a sua maneira, de Augusto Boal e de José Celso Martinez Corrêa, o Cinema Novo, e, o mais significativo para esta discussão, o Tropicalismo que, como se sabe, é um movimento que une as músicas dos compositores e cantores Caetano Veloso e Gilberto Gil, peças como "O rei da vela” de Oswald de Andrade, e "Roda Viva", de Chico Buarque, ambas dirigidas por José Celso Martinez Corrêa; filmes como "Macunaíma", de Joaquim Pedro de Andrade; além dos famosos "Parangolés", do artista plástico Hélio Oiticica. Na televisão, então já bastante difundida no Brasil, o programa do Chacrinha, que

2 SCHWARZ, Roberto. "Cultura e Política, 1964-1969". In: O Pai de familia e outros estudos. [1978] São Paulo: Companhia das Letras, 20o8, p.73. A partir de agora apenas as páginas do ensaio serão citadas entre parênteses.

3 Mais de quarenta anos mais tarde, quando os termos modernidade e modernização ganham larga circulação com a ideologia do neo-liberalismo do mercado globalizado, Fredric Jameson, em A Singular Modernity (2002), sugere que toda vez que lermos "modernidade" devemos substituir o termo por capitalismo, "só para ver o que acontece". Cf. JAMESON, Fredric. A Singular Modernity: Essays on the Ontology of the Present. London: Verso, 2002. 
misturava as classes sociais e os segmentos culturais e, no jornal, os textos de Nelson Mota, Ruy Castro e Torquato Neto são outras expressões do movimento.

Ainda que o crítico apresente esse momento luminoso da cultura nacional já sob o signo da derrota, que abre os olhos para as ambiguidades que aí já estão configuradas, fica o sentido da excepcionalidade de uma hora histórica em que há um forte nexo entre ebulição política e elaboração artística. De fato, até nossos dias esse momento de grandes realizações artísticas não foi igualado, assim como não o foram, até onde vão minhas luzes, a efervescência artística dos anos da República na Espanha ou do construtivismo na agora Rússia. A mistura potente de revolução política no horizonte do provável em uma sociedade em movimento dá impulso a uma inovação estética que confere à arte o valor que a vida sem escolhas lhe nega, ou seja, a de um ato social simbólico, uma intervenção no real que registra e esclarece uma situação histórica específica.

O ensaio examina como isso se dá no Brasil pré-golpe e nos anos que antecedem o endurecimento do AI-5, deslindando a tessitura complexa desse momento crucial do século XX brasileiro. A análise dessa produção cultural saturada de História e de possibilidades evidencia as contradições e superações e esclarece os termos da derrota do partido anticapitalista. A derrota política foi avassaladora, mas o legado desse tempo para o futuro é considerável, estabelecendo um marco que baliza as avaliações subsequentes. Isso também porque a cultura do período

chegou a refletir a situação dos que ela exclui e tomou seu partido. Tornou-se quase um abcesso no interior das classes dominantes. É claro que na base da sua audácia estava sua impunidade. Não obstante, houve audácia, a qual, convergindo com a movimentação populista num momento e com a resistência popular à ditadura noutro, produziu a cristalização de uma nova concepção do país. (p. 110).

Claro que essa nova concepção não se tornou hegemônica, mas algo da sua força permanece, nem que seja apenas como um horizonte contra o qual se mede onde estamos e que horas são. Essa mesma medida pode estar na base da decisão do nosso crítico de retomar o tema da figuração dos tempos na cultura no ensaio publicado em 2012. Ele revisita aí a obra de Caetano Veloso para aferir o percurso trilhado pelo que era visto como posição de esquerda nesses anos. O objeto desta vez é a autobiografia que Caetano tinha publicado em 1997, momento da consolidação 
do neoliberalismo no Brasil. A escolha, segundo Roberto Schwarz, é em princípio motivada pela força do livro, que, como os grandes romances realistas, revela um rumo social.

O crítico interpreta Caetano como uma personagem típica, no sentido empregado por Lukács para descrever as personagens ficcionais que encarnavam as contradições e as verdades das forças históricas em movimento em uma determinada formação social. Desse ângulo, Caetano personifica e revela por onde passam os caminhos que levam das aspirações e ambições de superação dos entraves do Brasil - o motor das grandes movimentações tanto políticas como culturais dos anos formativos para essa geração que hoje tem mais de 60 anos - às posições de uma “esquerda”, com muitas aspas, que diz fazer a única política possível. Pode ser que o tema das gerações seja um dos temas subjacentes ao ensaio, emoldurado por vários pontos de chegada em diferentes projetos: nas artes, Caetano, nascido em 1942, foi rebelde e é cantor e compositor de sucesso, pensador considerado, símbolo de uma liberação hedonista. Na crítica dialética, que pensa arte e sociedade, a obra de Schwarz, nascido em 1938, desenha um mestre na explicação da matéria brasileira e seus encadeamentos com o capitalismo contemporâneo. No plano da política real, Dilma Rousseff, nascida em 1947, ex-ativista de um grupo de guerrilha e prisioneira do Dops e da Oban nos anos pós-1964, é, como se sabe, presidente de um governo que se aproxima cada vez mais do centro e cada vez menos do socialismo como o conhecíamos. Seu mandato, de novo como se sabe, seguiu-se ao de Lula, nascido em 1945 e, antes dele, a Fernando Henrique Cardoso, nascido em 1931, e, como sabemos, ex-marxista, e um dos teóricos da influente teoria da dependência, que buscava, nos anos 1960, compreender o imbricamento do desenvolvimento nacional e os ditames do capitalismo internacional. Embora bastante diferentes entre si, essas figuras da vida nacional compartilham um ar do tempo ao qual cada um reage à sua maneira $\mathrm{e}$ dentro de seus projetos específicos. No plano da História compartilhada, destaca-se, é claro, o golpe de 1964, que vem pôr fim à efervescência política e floração cultural inéditas, assuntos do ensaio de 1970, quando, na aferição do próprio Roberto, as opções de mudança radical estavam em aberto. E isso em um país onde tradicionalmente em lugar de ruptura e de possível superação dos horizontes dados sempre se assiste à reposição da ordem antiga e à permanência de aspectos centrais da situação que se pensava ultrapassada.

O ano de 1964 representa uma hora histórica decisiva com consequências que reverberam até nossos dias. Um dos muitos focos de interesse do ensaio de 2012 é que tenta responder à questão central, ou 
seja, "Como foi que aquilo tudo deu nisso?" Como as ideias de superação do capitalismo por uma ordem mais justa dos anos pré-golpe foram superadas por sua vez pela acomodação à ordem vigente, ainda que posando de "outra coisa"? Que cara tem essa "esquerda acomodada" e o que ela pode nos ensinar a respeito do movimento histórico da vida brasileira, como apreendido por uma figura que concretiza de forma específica vários aspectos centrais das nossas condições objetivas? São essas algumas das perguntas que o ensaio de Roberto Schwarz suscita.

Ele as responde através de uma leitura cerrada do livro, deixando o seu objeto falar e demonstrando mais uma vez o potencial cognitivo da crítica dialética. Assinala, de saída, a originalidade da posição de um músico popular, adjetivo central para a discussão, que toma a si a tarefa de aferir sua prática e a de seus companheiros de ofício, à luz das opções estéticas e políticas de seu tempo, tema da autobiografia. E, em um país onde o "popular" não é associado à reflexão ou à crítica, nossa personagem o faz sem abandonar a relação com o público de massas, juntando em uma só pessoa o que a vida social coloca em posições antípodas, o intelectual e o pop star. A própria acepção de "popular" traz em si o conflito histórico: o sentido tradicional do termo se insere no campo semântico de "semi-analfabetismo, exclusão social, direitos precários". A acepção contemporânea, dada pelos meios de comunicação de massa, convive com a primeira dando notícia

do fato de que no Brasil, como noutros países periféricos, as duas acepções do popular se sobrepõem, pois as condições antigas não estão superadas, embora as novas sejam vitoriosas, o povo participando das duas esferas. Exclusão social - o passado? - e mercantilização geral - o progresso? - não são incompatíveis, como supõem os bem-pensantes, e sua coexistência estabilizada e inadmissível (embora admitida) é uma característica estrutural do país até segunda ordem. ${ }^{4}$

As reações ao que é "popular", "povo", exprimem as diferentes posições diante dessa característica.

O centro do programa estético e político dos anos pré-golpe é mudar essa estrutura histórica.

4 SCHWARZ, Roberto. Verdade Tropical: um percurso de nosso tempo. In: Martinha versus Lucrécia. São Paulo: Cia das Letras, 2012, p. 54. A partir de agora, apenas serão citadas as páginas deste ensaio, entre colchetes. 
Sob o signo da radicalização política, que beirou a pré-revolução, o programa tinha horizonte transformador. Em especial as artes públicas - cinema, teatro e canção - queriam romper com a herança colonial de segregações sociais e culturais, de classe e raça, que o país vinha arrastando e reciclando através dos tempos, e queriam, no mesmo passo, saltar para a linha de frente da arte moderna, fundindo revolução social e estética. Tratava-se por um lado de reconhecer a parte relegada e não-burguesa da nação, dando-lhe direito de cidade, e, por outro, de superar as alienações correspondentes a esta exclusão, que empobreciam a vida mental também dos incluídos. Graças ao espírito dialético, que estava em alta, os vexames de nossa malformação social - as feições de ex-colônia, o subdesenvolvimento - mudavam de estatuto. Em vez de varridos para baixo do tapete, eles passavam a ser identificados como interpelações históricas, em que estavam em jogo não só o atraso nacional como o rumo burguês e a desigualdade do mundo. $\{$ p. 55\}

Esse reconhecimento marca a geração que viveu o golpe e refletiu sobre suas consequências de um ponto de vista de esquerda, aí sem aspas: sem almejar a integração social não se pode falar em país moderno. Essa máxima estrutura a interpretação da realidade brasileira, a avaliação do que emperra sua mudança, e também os modos de inserção do nosso dito atraso no capitalismo internacional, cuja ideia de modernização é, necessariamente, excludente. Essa situação torna a figura de Caetano exemplar e aumenta o interesse de especificar o giro de posição, que a leitura de Roberto Schwarz demonstra na biografia de 1997. Esse giro é a expressão de uma estrutura de sentimento ${ }^{5}$ que vai dominar a paisagem política e intelectual até nossos dias. Nesse sentido, a autobiografia registra a mudança de perspectiva e de tom, e a construção de uma retórica e de um argumento que se tornarão hegemônicos na Esquerda de hoje.

Caetano está no centro de uma série de convergências: é músico popular; tem formação no campo da esquerda onde, como veremos, ainda se imagina; foi preso pelo regime militar; é líder, ao lado de Gilberto Gil, de um movimento cultural de grande alcance, que procura figurar um aspecto chave da vida nacional, precisamente a convivência

5 Estrutura de sentimento é expressão cunhada por Raymond Williams para descrever com atua a determinação sócio-histórica nos modos de pensar, produzindo algo tão firme como uma estrutura e tão inefável como sentimentos. O termo procura dar conta de uma área da experiência que é material e social, mas ainda não totalmente articulada. Cf. CEVASCO, Maria Elisa. Para ler Raymond Williams. São Paulo: Paz e Terra, 20oı. 
entre o antigo (o atraso) e o contemporâneo (a substituição do atraso pela inserção subalterna no mercado moderno). Como se há de recordar, o procedimento formal básico do tropicalismo em sua primeira hora (vale lembrar o penico e foto de formatura na capa ultracontemporânea do disco Panis et circencis (sic) de 1968) buscava submeter o arcaico a procedimentos ultracontemporâneos como a montagem, os arranjos musicais do rock internacional, o uso de guitarras elétricas e as citações de vanguarda. Já no ensaio de 1970, Roberto reconhecia que o movimento alcançava uma explicitação artística das características da vida na periferia do capitalismo poucas vezes igualada em nitidez:

...A coexistência do antigo e do novo é um fato geral, e sempre sugestivo de todas as sociedades capitalistas e de muitas outras também. Entretanto, para os países colonizados e depois subdesenvolvidos, ela é central e tem força de emblema. Isso porque esses países foram incorporados ao mercado mundial - ao mercado moderno - na qualidade de econômica e socialmente atrasados, de fornecedores de matéria prima e trabalho barato. A sua ligação ao novo se faz através, estruturalmente através de seu atraso social, que se reproduz em vez de se extinguir. Na composição insolúvel mas funcional dos dois termos, portanto, está figurado um destino nacional que dura desde os inícios. (p. 91).

Fica claro que palavras como "insolúvel" e "destino nacional" já indicam a perspectiva tropicalista sobre o país, cujas contradições são figuradas como impossíveis de superar, entendimento que está na base da virada que a autobiografia de 1997 especifica. Em que momento nosso herói típico compreende a tal inelutabilidade do destino nacional? Como ele representa essa compreensão histórica na narrativa de seu destino individual? A leitura de Schwarz segue rente à explicação de Caetano de como isso se dá. Tudo começa, como para tantos de classe média nessa geração, por uma adolescência rebelde e do "contra". No caso de Caetano, a rebeldia o leva a forjar para si o papel de "guarda avançada da crítica e da mudança”, papel reforçado quando sai de sua cidadezinha natal (de novo um movimento típico da época em que quase só havia universidades nas capitais), vai para Salvador, então já embalada pela ebulição política e cultural dos anos pré-golpe, onde vivencia o que Roberto Schwarz define como "o encontro explosivo - e formador - de experimentalismo artístico sem fronteiras nacionais, subdesenvolvimento, radicalização política, cultura popular onipresente e província, além da hipótese socialista no horizonte." \{p. 63\} 
Esse, então, o espaço formador da geração. Nas palavras de Caetano, podemos ver a descrição de como as diferentes esferas da vida social se interligam e expressam, cada uma a seu modo, a potência organizadora da oportunidade histórica de enfim mudar o passo brasileiro. $\mathrm{O}$ interessante dessas palavras é que mostram como o momento histórico estrutura a experiência do vivido:

Falávamos de literatura, cinema, música popular; falávamos de Salvador, da vida na província, da vida das pessoas que conhecíamos; falávamos de política. Alvinho [um amigo] tinha rompantes heroicos: acho que foi ele quem me decidiu a colaborar com a campanha de alfabetização pelo método Paulo Freire (mais tarde, depois do golpe, ele me levou a alguns encontros secretos para a formação de um "grupo dos onze", uma ideia de Leonel Brizola para organizar a resistência). Embora política não fosse nosso forte nessa época - 63 - com os estudantes (organizados na UNE) apoiando o presidente João Goulart, ou pressionando-o para ir mais à esquerda; com Miguel Arraes fazendo um governo admirável em Pernambuco em estreita união com as camadas populares, com os CPCs da UNE produzindo peças e canções panfletárias mas muito vitais; éramos levados a falar frequentemente de política: o país parecia à beira de realizar reformas que transformariam a sua face profundamente injusta - e de alçar-se acima do imperialismo americano. Vimos depois que não estava sequer aproximando-se disso. E hoje nos dão bons motivos para pensar que talvez nada disso fosse propriamente desejável. Mas a ilusão foi vivida com intensidade - e essa intensidade apressou a reação que resultou no golpe. ${ }^{6}$

Se fizermos uma descrição um pouco mais detida desse parágrafo vemos que sua ordem vai assinalando as oscilações da formação de Caetano. Acho a primeira sentença particularmente reveladora, e é ela que dá o ritmo do parágrafo: no olho do furacão, a turma de Caetano, como tantas outras, fala de política e da vida alheia, na mesma hierarquia. Política não era - e será que agora é? -, o forte, mas isso não impede que ele se engaje nos grandes movimentos da época, embora, de novo o ritmo de vai e vem, faça-o de maneira fortuita (o amigo o convence a participar da campanha de alfabetização do método Paulo Freire e do grupo dos onze, as peças do CPC eram panfletárias mas vitais). A

6 VELOSO, Caetano. Verdade tropical. São Paulo: Cia das Letras, 1997, p. 63-4. 
avaliação da conjuntura é exata: o país à beira das reformas, perto de enfim transformar sua face injusta e dar as costas ao capital internacional. Em seguida a reversão total, mas agora o nós, que antes parecia se referir a ele e aos amigos dá a impressão de se generalizar, suscitando no leitor atento a pergunta "Nós quem?". Essa indeterminação é ainda mais problemática na frase do recuo final: "hoje nos dão bons motivos para pensar que talvez isso não fosse propriamente desejável." Quem dá essas razões? O que não é propriamente desejável? Transformar a face injusta do país? Alçar-se acima do imperialismo norte-americano? Mudar?

Voltando à análise de Roberto Schwarz. Ele assinala como Caetano conta o momento da revelação dos "erros" da esquerda revolucionária. Esse momento se dá, talvez como não podia deixar de ser para um artista, através de uma experiência estética: no caso, o de sua reação, depois testada e corroborada pelas acaloradas discussões que marcaram esses tempos em que o destino do país estava em disputa, a uma cena do filme símbolo da produção desses anos, o Terra em transe (1967) de Glauber Rocha. Trata-se da cena em que a personagem Paulo Martins, um intelectual de classe média, exasperado com a subserviência de um líder sindical que, no meio de uma manifestação, chama-o de doutor, tapa a boca do líder e dirige ao público a pergunta "Estão vendo quem é o povo? Um analfabeto, um imbecil, um despolitizado". A cena é certamente carregada de ambiguidades e enfeixa uma série de posições correntes na esquerda da época. Na leitura de Roberto elas ficam assim enumeradas:

Meio sádico, meio auto-flagelador, o episódio sublinha entre outras coisas a dubiedade do intelectual que se engaja na causa popular ao mesmo tempo em que mantém as avaliações conservadoras raramente explicitadas como aqui - a respeito do povo. Ditada pela evidência de que não haveria revolução, a desqualificação dos trabalhadores é um desabafo histórico, que no passo seguinte leva à aventura da luta armada sem apoio social. Do ponto de vista da esquerda, a cena - uma invenção artística de primeira força - era um compêndio de sacrilégios, fazendo uma espécie de chacota dolorosa das certezas ideológicas do período. Os trabalhadores estavam longe de ser revolucionários, a sua relação com os dirigentes pautava-se pelo paternalismo, os políticos populistas se acertavam com o campo adversário, a distância entre as teses marxistas e a realidade social era desanimadora, e os intelectuais confundiam as razões da revolução política e as urgências da realização pessoal. Nem por isso se atenuavam as feições grotescas das 
camadas dirigentes e da dominação de classe, que continuavam em pé, esplendidamente acentuadas. A revolução não se tornara supérflua, muito pelo contrário: encontrava-se num beco histórico e não dera o necessário passo à frente. A nota geral era de desespero. $\{$ p. $76-77\}$

A força de revelação da cena está justamente em mostrar com economia e poder de alusão como o choque de realidade do golpe desorganiza as posições de esquerda em vários níveis, interroga suas certezas e demonstra sua derrota acachapante. $\mathrm{O}$ fato de que Paulo Martins morre no fim do filme com uma metralhadora na mão prefigura a luta armada, que teve as consequências que eram amplamente conhecidas quando Caetano escreve a autobiografia. Mas nela a cena tem outro tom e vale a pena citá-la na íntegra para especificar como se dá o passo da esquerda revolucionária que deseja libertar a todos para a posição libertária e rebelde que iria constituir o núcleo da nova era que se anuncia:

Vivi essa cena - e as cenas de reação indignada que ela suscitou em rodas de bar - como o núcleo de um grande acontecimento cujo nome breve que hoje lhe posso dar não me ocorrera com tanta facilidade então (e por isso eu buscava mil maneiras de dizê-lo para mim mesmo e para os outros): a morte do populismo. (...) era a própria fé nas forças populares - e o próprio respeito que os melhores sentiam pelos homens do povo - o que aqui era descartado como arma política ou valor ético em si. Essa hecatombe eu estava preparado para enfrentá-la. E excitado para examinar-lhe os fenômenos íntimos e antever-lhe as consequências. Nada do que veio a se chamar de 'tropicalismo' teria tido lugar sem esse momento traumático.

(...)

Portanto, quando o poeta de Terra em transe decretou a falência da crença nas energias libertadoras do 'povo', eu, na platéia, vi, não o fim das possibilidades, mas o anúncio de novas tarefas para mim. ${ }^{7}$

Para seguir nesse cotejo das diferenças de posição entre o crítico e seu objeto, vale a pena citar na íntegra a leitura que Schwarz faz do episódio. Segundo ele:

7 VELOSO, Caetano. Verdade tropical, p. 104-105 (primeiro fragmento) e 116 (segundo fragmento). 
Convém notar que 'populismo' aqui não está na acepção sociológica usual, latino-americana, de liderança personalista exercida sobre massas urbanas pouco integradas. No sentido que lhe dá Caetano, o termo designa algo de outra ordem. Trata-se do papel especial reservado ao povo trabalhador nas concepções e esperanças da esquerda, que reconhecem nele a vítima da injustiça social e, por isso mesmo, o sujeito e aliado necessário a uma política libertadora. O respeito que 'os melhores' sentiam - e já não sentem? - pelos homens do povo, semi-excluídos e excluídos, em quem contemplavam a dura verdade de nossa sociedade de classes, liga-se a esta convicção. 'Ou talvez seja eu próprio que me despreze a seus olhos', escrevia Drummond em 1940, pensando no operário $^{8}$. Assim, quando Caetano faz suas as palavras de Paulo Martins, constatando e saudando através delas a 'morte do populismo', do 'próprio respeito que os melhores sentiam pelos homens do povo', é o começo de um novo tempo que ele deseja marcar, um tempo em que a dívida histórico-social com os de embaixo - talvez o motor principal do pensamento crítico brasileiro desde o Abolicionismo - deixou de existir. Dissociava-se dos recém-derrotados de 64 , que nessa acepção eram todos populistas. A mudança era considerável e o opunha a seu próprio campo anterior, a socialistas, nacionalistas e cristãos de esquerda, à tradição progressista da literatura brasileira desde as últimas décadas do século XIX, e, também, às pessoas simplesmente esclarecidas, para as quais há muito tempo a ligação interna, para não dizer dialética, entre riqueza e pobreza é um dado da consciência moderna. A desilusão de Paulo Martins transformara-se em desobrigação. Esta a ruptura, salvo engano, que está na origem da nova liberdade trazida pelo Tropicalismo. Se o povo, como antípoda do privilégio, não é portador virtual de uma nova ordem, esta desaparece do horizonte, o qual se encurta notavelmente. \{p. 78-9\}

É nesse momento que Caetano, para usar a expressão certeira e totalmente inserida no contexto de José Miguel Wisnik em seu comentário sobre o ensaio, dá o salto que o leva de "Capitu a Brás Cubas". Pode-se acrescentar que isso torna Caetano tão típico da subjetividade forjada pela derrota do campo anticapitalista quanto o protagonista de

8 ANDRADE, Carlos Drummond de. "O operário no mar". In: Sentimento do mundo.

9 WISNIK. José Miguel. Versus. O Globo, 28 de abril de 2012. Disponível em: http:// www.trela.com.br/arquivo/versus Acesso em: 21 jul. 2014. 
Machado é típico da subjetividade que se forma nas contradições acirradas do sistema na periferia. Claro que, dadas as condições históricas, Caetano poderia ter sido uma Capitu ou uma Helena Morley, espíritos desabusados que não se curvam com facilidade e gosto às injunções dos tempos. O crítico acompanha com aprovação os capítulos da formação de nosso protagonista, a infância inconformada, a exposição ao fermento político e à bossa nova, em especial à produção de João Gilberto. Roberto Schwarz classifica como extraordinária a percepção de Caetano do que efetivamente embasa a grandeza da realização artística de João Gilberto. Para o crítico, Caetano dá aí um verdadeiro "olé dialético" ao apresentar sua avaliação do significado real da invenção artística de João

o cantor popular, pela originalidade da dicção musical que desenvolveu, é dito 'um redentor da língua portuguesa, como violador da imobilidade social brasileira - da sua desumana e deselegante estratificação - como desenhador das formas refinadas e escarnecedor das elitizações tolas que apequenam essas formas'. ${ }^{10}$

A avaliação sobre o golpe também é certeira: “(...) víamos no golpe a decisão de sustar o processo de superação das horríveis desigualdades sociais brasileiras e, ao mesmo tempo, de manter a dominação norteamericana no hemisfério". ${ }^{11}$ Vê-se então que nosso protagonista tem consciência clara e esclarecida do que se dá à sua volta.

O momento Brás Cubas vem quando Caetano avalia, com razão, que o golpe marca também a derrota de um modo de pensar, aquele que considerava que as classes oprimidas teriam que fazer a revolução para que todos fossem livres. A transformação, embora anunciada nos momentos de vai e vem da exposição de Caetano, é surpreendente. Forçando um pouco a analogia, é como se Capitu, tendo entendido que Bentinho não vai mudar e que seu modo de pensar é o vencedor, capitulasse e resolvesse ser uma esposa no modo do vigente. Nosso protagonista percebe corretamente (realisticamente diria certa esquerda de nossos dias) que o golpe era um momento chave não só da história do Brasil, onde o realinhamento de classes se dava em aliança com o capital estrangeiro, como também da Guerra Fria, quando a dominação norte-americana se consolidava no hemisfério, todos unidos para implantar o projeto de modernização excludente que marcaria os anos do milagre e os seguintes. O momento encerra, é claro, a derrota de um modo de pensar,

10 VELOSO, Caetano. Verdade tropical, p. 502.

11 VELOSO, Caetano. Verdade tropical, p. 177. 
que é um dos conteúdos, como vimos aqui, da cena de Terra em transe: o povo oprimido tem que fazer a revolução para que todos sejam livres. Como não o fez, a conclusão que tiram alguns, entre eles certamente nosso protagonista, é de que, para usar a linguagem clássica, não é mais possível a luta de classes. Claro que esse é um dos ideologemas chave dos vencedores da Guerra Fria, o qual ia dominar o cenário mundial até nossos dias. O que torna Caetano típico do que estou tentando caracterizar como a esquerda conformada é que isso para ele é uma liberação e uma abertura para novos tipos de política, notadamente a política de identidades, todas elas muito bem intencionadas e nenhuma anticapitalista, e todas se furtando de enfrentar o fato de que essas políticas, assim como as posições ecológicas mais recentes, não se podem realizar totalmente a perdurar a situação atual.

É possível dizer que esse ponto continua central e traumático, em especial para a geração que viveu o momento luminoso das possibilidades. Veja-se como ele retorna na apreciação de José Miguel Wisnik sobre o ensaio de Roberto. Ele concorda que a reação a Terra em transe é emblemática de um giro no percurso de Caetano, mas discorda da avaliação de que este giro o leva a aderir aos que desqualificam as forças populares: "O entusiasmo a que a passagem da cena de Terra em transe se refere é mais propriamente o de avizinhar-se de uma nova forma mental, ligado ao momento libertador, entre transe e esclarecimento, promovido pela queda de tabus". ${ }^{12}$

Concordo plenamente que se trata de uma nova forma mental, embora tenha dificuldades de pensar essa forma nos termos mais propriamente psíquicos de um transe. Qual o tabu que cai? O do sentimento geral de que era preciso integrar o povo em qualquer projeto social digno desse nome? Em que medida isso abre possibilidades? Qual o preço social e, em última análise, o custo humano, dessa nova posição excludente? Caetano acerta ao ver aí o que ele chama de "a morte do populismo". Em Verdade tropical ele elabora as consequências:

O golpe no populismo de esquerda libertava a mente para enquadrar o Brasil de uma perspectiva ampla, permitindo miradas críticas de natureza antropológica, mítica, mística, formalista e moral $^{13} \mathrm{com}$ que nem se sonhava... era a retórica e a poética da

12 WISNIK, José Miguel. Versus.

13 Note-se que Roberto Schwarz acerta na mosca ao observar que as tais miradas críticas de diferentes naturezas eram uma volta ao passado das velhas avaliações do Brasil. 
vida brasileira do pós-64: um grito fundo de dor e revolta impotente, mas também um olhar atualizado, quase profético, das possibilidades reais, para nós, de ser e de sentir. ${ }^{14}$

Não se trata de defender aqui o populismo realmente existente no pré-1964. Embora não seja estudiosa do assunto, tendo a concordar com a avaliação de Roberto Schwarz de que este populismo era uma "estranha confluência entre capital e trabalho em torno de uma entidade mítica", no caso, "uma visão apologética e sentimentalizável, que abraçava indistintamente as massas trabalhadoras, o lumpesinato, a intelligentsia, os magnatas nacionais e o exército" (p. 76). Mas o fato é que o giro preparava a entrada de um novo tipo de oposição, liberta, como diria Caetano, do fardo dos pobres e pronta a juntar-se à novíssima esquerda ocidental. Como se sabe, após as derrotas dos anos 1960, abandona-se por toda a parte a ideia de oposição e de ruptura com o modelo econômico substituída pelo "dissenso mercantilizado dos diferentes estilos de vida", nome de uma coletânea de ensaios publicada em Nova Iorque que procura desenhar esta virada ${ }^{15}$. Nesse sentido, a tipicidade de Caetano tem contorno mais global e ajuda a entender tanto a situação local quanto a internacional que a determina, e o faz a partir da reação a um momento central da conjuntura atual. Como se sabe, o golpe de 1964 não foi apenas um caso singular, mas a instância mais dramática de um fenômeno global, o do começo da vitória dos Estados Unidos e seus aliados na Guerra Fria, que levaria à consolidação da hegemonia americana no capitalismo de mercado, o que se chama hoje de globalização. $O$ nexo ideológico dessa nova forma de funcionamento do velho sistema é o da "modernidade singular", formulação, como vimos, de Jameson para dizer a volta da obsessão com o "moderno" em pleno pós-moderno, agora como a ideologia central do tempo da dominação inconteste do capitalismo do mercado "livre" por todo o globo. Basta lembrar como é "pouco moderno" em nossos dias o estado do bem-estar social, ou a proteção à indústria nacional, ou aos direitos dos trabalhadores. Para voltar a 1964, claro que os militares ao tomar o poder no Brasil instauraram nada mais nada menos do que um processo de modernização do país, sem nenhuma pretensão de que essa modernização seria para todos.

Um dos muitos efeitos da colonização do termo pelo sistema vigenteé que relega os esforços anticapitalistas à posição contrária, de antigo, fora de

14 VELOSO, Caetano. Verdade tropical, p. 105-106.

15 Esse trabalho é citado por BROWN, Nicholas. Utopian Generations. Princeton: Princeton University Press, 2005, p. 188. 
moda,algoprontoparairparaalatadelixodahistória.Nocampodaprodução artística esse realinhamento marca o fim do que Nicholas Brown chama de "modernismo político fundado em grandes projetos utópicos" ${ }^{16} \mathrm{e}$ o começo da indistinção que marca o momento contemporâneo do pós-moderno.

A produção artística de Caetano foi e é emblemática das formas da inserção do nacional no campo de forças internacional. A instauração do Tropicalismo, como ressalta Roberto Schwarz no ensaio de 1970, correspondeu a uma nova situação, o momento em que o arcaico (as estruturas antigas da formação social brasileira) se combinaram com o moderno cujo sentido, nessa hora histórica, ainda estava em disputa.

Enquanto na fase Goulart a modernização passaria pelas relações de propriedade e poder, e pela ideologia, que deveriam ceder à pressão das massas e das necessidades de desenvolvimento nacional, o golpe de 1964,...firmou-se pela derrota desse movimento, através da mobilização e confirmação, entre outras, das formas tradicionais e localistas de poder. Assim, a integração imperialista que em seguida modernizou para seus propósitos a economia do país, revive e tonifica a parte do arcaísmo ideológico e político de que necessita para a sua estabilidade. De obstáculo e resíduo, o arcaísmo passa a instrumento intencional da opressão mais moderna, como aliás a modernização, de libertadora e nacional, passa à forma de submissão. (p. 86-87)

O procedimento formal básico do Tropicalismo reside, como vimos pelas lentes de Roberto Schwarz, em dar materialidade a essa fusão do antigo e do moderno, justapondo imagens do atraso e procedimentos contemporâneos. O movimento logrou uma integração total ao mercado, onde ocupa o nicho de "dissidentes". Que essa dissidência seja totalmente palatável dá notícia do acerto dos tropicalistas que lograram uma fórmula que diz muito da modernização à brasileira. Aprendemos com ele, já em seu ensaio de 1977, "Idéias fora do Lugar"17 que uma das peculiaridades mais reveladoras do funcionamento do Brasil é justamente o fato de que a cada momento de superação - basta lembrar a Independência, o Abolicionismo, a República -, o Brasil historicamente repõe vários elementos da fase que se pensava superada. O Tropicalismo registra o momento da dissolução da liga potente entre forças históricas em disputa, artistas

16 BROWN, Nicholas. Utopian Generations, p. 188.

17 SCHWARZ, Roberto. Ideias fora do Lugar. In: Ao vencedor, as batatas. São Paulo: Duas Cidades, 1977. 
em busca de processos de uma arte popular, experimentalismo estético e opções políticas radicais que marcaram o período pré-golpe. Nessa etapa, em plena ditadura militar, o impulso esquerdizante, de revolucionário torna-se rebelde e, longe de reivindicar a mudança das relações de propriedade, aponta para uma versão localizada de política, ligada à liberação dos costumes, uma liberação do corpo e do desejo, mais do que das massas oprimidas. A própria questão das formas de integração com o capitalismo internacional, central para um país periférico, é deixada de lado. A integração em si importa mais do que seus termos. É significativo que Caetano Veloso, recordando de como o nome "Tropicália" foi tirado de uma instalação de Hélio Oiticica, nos diga que não gostava do nome porque reduzia o que ele entendia de sua música a uma "reles localização geográfica." ${ }^{18}$ Outro ponto negativo, para o compositor que ensaiava formas de integração com o internacional, era que a

palavra tropicalismo me soava conhecida e gasta, já a tinha ouvido significando algo diferente, talvez ligado ao sociólogo pernambucano Gilberto Freyre (o que mais tarde se confirmou), de todo modo, algo que parecia excluir alguns dos elementos que nos interessava ressaltar, sobretudo aqueles internacionalizantes, antinacionalistas, de identificação necessária com toda a cultura urbana do Ocidente. ${ }^{19}$

Se antes a questão era pensar centro e periferia como interconstituintes e como uma divisão superável apenas em um horizonte pós-capitalista, em uma ordem mundial renovada cujas possibilidades estavam dadas em muitos países nos anos 1960, para os tropicalistas a questão era experimentar novas posições de sujeito nessa relação vista como palatável e impossível de mudar. Enfim, o futuro estava mais para os tropicalistas do que para os anseios revolucionários.

E, no entanto, esses anseios voltam a assombrar. Schwarz termina sua avaliação sobre nosso herói típico assinalando a generalidade deste percurso de nosso tempo:

Escrito com distância de três décadas, em plena normalização capitalista do mundo nos anos 90, Verdade tropical recapitula a memorável efervescência dos anos 60, em que o Tropicalismo figurava com destaque. Bem vistas as coisas, a guerra de atrito com a

18 VELOSO, Caetano. Verdade tropical, p. 188.

19 Idem, ibidem, p. 192. 
esquerda não impediu que o movimento fizesse parte do vagalhão estudantil, anti-capitalista e internacional que culminou em 1968. Leal ao valor estético de sua rebeldia naquele período, Caetano o valoriza ao máximo. Por outro lado, comprometido também com a vitória da nova situação, para a qual o capitalismo é inquestionável, o memorialista compartilha os pontos de vista e o discurso dos vencedores da guerra fria. Constrangedora, a renúncia à negatividade tem ela mesma valor de documento de época. Assim, a melhor maneira de aproveitar este livro incomum talvez inclua uma boa dose de leitura a contrapelo, de modo a fazer dele uma dramatização histórica: de um lado o interesse e a verdade, as promessas e as deficiências do impulso derrotado; do outro, o horizonte rebaixado e inglório do capital vitorioso. \{p. 110\}

Seria tentador terminar esta minha tentativa de interpretação nessa altura em que Schwarz coloca o debate, mas a reação $0^{20}$ que seu ensaio provocou é de tal ordem que me sinto tentada a arriscar uma interpretação que, embora me obrigue a dialogar com algumas dessas reações, pode ajudar a desentranhar um conteúdo mais esperançado da negatividade da crítica. Explico: a imprensa brasileira, tradicional caixa de ressonância do espírito dominante, deu um destaque excepcional ao livro. O excepcional não se refere, óbvio, à qualidade da obra, mas ao fato de se dar destaque a uma posição declaradamente marxista, esta corrente tão pouco "moderna”. Assim, a Folha de São Paulo, antes mesmo de o livro sair, entrevistou Caetano, que tivera acesso ao ensaio antes da publicação. Ele se declara envaidecido com a atenção dispensada pelo crítico, mas se ressente do fato de que os que ele chama de "elegantes uspianos", e nomeia Marilena Chauí e o próprio Roberto Schwarz, nunca dizem nada da "Coréia do Norte". O que isso tem a ver com a discussão em pauta sobre visões do Brasil eu não sei, a menos que haja alguma conexão, que não sou capaz de especificar, com a apreciação que Caetano faz de Mangabeira Unger, que, segundo ele,

20 Há resenhas acadêmicas em outro tom, como por exemplo, a de OHATA, Milton. Roberto Schwarz e o progresso à brasileira. Piaui, n. 69, e de RODRIGUES, Lidiane Soares. Martinha versus Lucrécia: ensaios e entrevistas. Tempo social, São Paulo, v. 24, n. 1, 2012. DOI: http://dx.doi.org/10.1590/So103-20702012000100016, e a de PILATI, Alexandre. Verdade versus Análise, Disponível em: http://outraspalavras.net/ posts/verdade-versus-analise/ Acesso em: 11 jul 2014; e também a de GONÇALVES, Anderson; OTSUKA, Edu Teruki; RABELLO, Ivone Daré. O retratista e os intelectuais: às voltas com 1964. Revista do Instituto de Estudos Brasileiros, São Paulo, n. 57, dez. 2013. DOI: http://dx.doi.org/10.1590/Soo20-38742013000200014. 
abre espaço para a originalidade do Brasil. Para mim isso é fatal: somos originais, seremos originais, ou desapareceremos. O capitalismo não é inquestionável. ...Sou contra [a sociedade do lucro]. Mas não quero que os que lutam contra isso possam ganhar poderes autocráticos. Uma revolução feita a partir da originalidade benigna de um Brasil de sonho deveria não precisar ser sangrenta e poderia, de qualquer modo, orientar os serviços que alguém queira prestar à Justiça de um jeito diferente daquele que tem sido desenvolvido pelos movimentos revolucionários da esquerda convencional. Eles têm levado à autocracia e a Estados policiais. Sou contra. Além disso, quando se diz 'capitalismo', o que mesmo que se diz? ${ }^{21}$

Penso que se apresentam aí algumas das características que tornam posições como a de Caetano tão palatáveis: por um lado apela ao imaginário mais conservador ao destacar apenas a herança pesada e real do socialismo efetivamente existente - todos à esquerda e à direita, se é que se pode nessa ótica falar assim, desaprovam e, em especial a esquerda, tem que dar conta desse peso. Outro passo peculiar é o da solução fantasiosa do Brasil de sonho, baseada na excepcionalidade nacional que sempre foi o mantra das classes dominantes para justificar seus privilégios, mas apela ao narcisismo geral de sermos todos únicos. E isso sem contar que, no contexto de um mundo de produção e comércio globalizados sob a égide do capital, fica difícil manter qualquer pretensão de originalidade. Ainda mais um, é o da negação de que o capitalismo seja identificável - provavelmente porque é hoje o estado natural do mundo? Note-se também a reiteração da posição subjetiva "Sou contra" como instância explicativa. Mesmo assim, e atestando que o espírito dos anos 60 ainda assombra, Caetano reitera que

Minha teimosia em permanecer no campo da esquerda vem da minha crença na possibilidade de mudar para melhor o jeito de a gente viver sobre a Terra. Não descarto sequer a eventualidade de alguma violência. [e aí vem o vai e vem que aprendemos a reconhecer] Mas estou certo de que o que se chama de esquerda também atrapalha muito. ${ }^{22}$

21 VELOSO, Caetano. Folha de São Paulo, 15 de abril de 2012, p. 5 .

22 Idem. ibidem. 
Parece que o jornalista esportivo Juca K foury acertou ao comentar sem ironia a entrevista de Caetano com a conclusão de que este é o "representante da esquerda moderna". Falta acrescentar que moderno aí exemplifica o exercício sugerido por Jameson e ganhamos em compreensão ao substituir moderno por capitalista.

Nas resenhas mais propriamente literárias aparece o desconforto que uma tomada de posição clara gera em nossos termos dominados pelo relativismo, uma das manifestações ideológicas de um período histórico que se apresenta como um momento em que, sempre segundo essa ideologia, não haveria alternativas ao que existe. Assim, o resenhista da Folha de São Paulo lamenta o "contrapeso ideológico" do texto que, se não fora por isso, estaria "cheio de boas análises e ideias". E explica que

no intuito talvez de compensar a bancada marxista por deixarse enfeitiçar pelo Tropicalismo e seu herói, mesmo quando sua atitude 'transgressora e libertária' já rechaçava igualmente os establishments de esquerda e direita, Schwarz move-se segundo uma dialética (sic) de elogio e reprimenda.

A destacar, além da incompreensão do movimento do ensaio, a ideologia de se pensar o trabalho da crítica como o de elogiar ou reprimir, ou, na linguagem do jornal, dar estrelas. Veja-se aí uma das muitas perdas, do rebaixamento do horizonte ideológico que vem junto, como mostra Roberto Schwarz, com a renúncia a questionar o que existe.

O resenhista da Veja merece ser citado de forma mais extensa porque mostra, também de forma muito rebaixada, o estrago que a acomodação ao vigente faz na capacidade crítica. Começando pelo papel reduzidíssimo que confere à crítica literária:

Como Schwarz é um crítico marxista ou, pelo menos, de esquerda, ele tem assuntos mais importantes a discutir: as desigualdades sociais e a luta de classes, o desequilíbrio das relações internacionais e o imperialismo americano, as deformações da história brasileira e as injustiças que estas teriam gerado etc. Tudo isso não só eclipsa as questões propriamente literárias, como, por assim dizer, as sobredetermina, de modo que qualquer obra só tem valor na medida em que de algum modo as reflita e tome partido (aquele que o ensaísta julgue correto). Assim termos como "capital" e 
"capitalismo" são bem mais fáceis de achar neste volume do que palavras como, digamos, "sinédoque", "anacoluto", ou "barroco". ${ }^{23}$

Claro que a posição de que falar de anacoluto é mais importante do que de capitalismo é indefensável em qualquer clima ideológico, mas vale observar a insistência em aliar "tomar partido", ter posições sobre o mundo é associado a autoritarismo. De novo Jameson tem a descrição do que a indistinção pós-moderna faz com a discussão intelectual: um dos efeitos da corrente de pensamento pós-estruturalista, não por acaso, o pensamento dominante no momento neoliberal, foi modificar os contornos das disputas discursivas. ${ }^{24}$ A partir de agora, nenhum código explicativo pode reivindicar sua correção ou preponderância sobre os outros, todos têm que se colocar como "opcionais" e conviver no mercado das teorias. Ai do código que reivindicar uma posição clara ou um diagnóstico contundente que ameace o consenso do coro dos contentes.

Nessa situação, a avaliação do contemporâneo feita por Roberto Schwarz, assim como a demonstração do que se perdeu com a derrota do partido da mudança radical, só pode, como foi o caso, resultar em reações desmedidas, que acusam o golpe. Para os que aspiram ainda a um mundo diferente, estas reações provocam uma esperança: se o antimarxismo está tão vivo e latejante, será possível afirmar que seu antagonista, não só como a instância da crítica ao vigente, mas também como demonstração da necessidade de mudar, ao contrário do que dizem, não morreu? Os ensaios de Roberto Schwarz são uma resposta incisiva a esta questão recorrente.

\section{Sobre a autora}

\section{Maria Elisa Cevasco}

Professora titular da FFLCH-USP. Bolsista em Produtividade em Pesquisa do CNPq - Nível 2. Possui graduação em Letras - Português/Inglês, mestrado e doutorado em Estudos Linguísticos e Literários em Inglês pela mesma instituição. E-mail:maece@usp.br

23 ASCHER, Nelson. O Crítico Justiceiro. Veja. 2 de maio de 2012, p.138.

24. JAMESON, Fredric. Postmodernism or the Cultural Logic of Late Capitalism. Durham: University of North Carolina Press, 1991, p.391-399. 